Acta vet. scand. $1977,18,257-265$.

From the Department of Clinical Chemistry and the Department of Obstetrics and Gynaecology, Royal Veterinary College, Uppsala, and

the Department of Chemistry, Karolinska Institutet, Stockholm, Sweden.

\title{
PROSTAGLANDIN RELEASE AT DEXAMETHASONE INDUCED PARTURITIONS IN COWS*
}

\author{
By \\ Jan-Otto Lindell, Hans Kindahl and Lars-Eric Edqvist
}

\begin{abstract}
LINDELL, J.-O., H. KINDAHL and L.-E. EDQVIST: Prostaglandin release at dexamethasone induced parturitions in cows. Acta vet. scand. 1977, 18, 257-265. - Three cows of the Swedish Red and White Breed (SRB) were used in the experiment. Cow no. 1 pregnant for 247 days, was given $20 \mathrm{mg}$ dexamethasone twice with an interval of $48 \mathrm{hrs}$. Cows nos. 2 and 3 , each pregnant for 254 days, received $20 \mathrm{mg}$ of dexamethasone twice with an interval of $24 \mathrm{hrs}$. The cows delivered normal living calves 153,138 and $137 \mathrm{hrs}$., respectively, after the second injection of dexamethasone. Blood samples were drawn from the jugular vein every third hour during the experimental period and the samples were analyzed for estrone, progesterone and 15-keto-13,14dihydroprostaglandin $F_{2} \alpha$. Following the dexamethasone injections there was a continuous increase in the blood plasma levels of estrone followed by a sharp decrease in conjunction with parturition. The blood plasma level of progesterone showed a slow but continuous decrease until about $24 \mathrm{hrs}$. before delivery when a marked drop occurred. The levels of the prostaglandin metabolite increased gradually until about $24 \mathrm{hrs}$. prior to delivery. This was followed by an abrupt rise, and high levels of the prostaglandin metabolite were recorded for up to four days following parturition. It is concluded that the estrone increase preceded that of the prostaglandin metabolite and that the final drop in the progesterone was synchronous with the final rise of the prostaglandin metabolite level.
\end{abstract}

prostaglandin release; estrone; progesterone; dexamethasone induced parturition; bovine.

* This investigation was supported by the Swedish Council for Forestry and Agricultural Research and by the World Health Organization. 
Dexamethasone $^{\star}$ administered to the dam induces premature parturition in the bovine species (e.g. Adams \& Wagner 1970, Edquist et al. 1972, Hoffman et al. 1973). The pattern of estrogen and progesterone levels seen in peripheral blood plasma before dexamethasone induced parturitions in the cow follows closely the pattern of these hormones before spontaneous parturitions (Edqvist et al. 1972, 1973). Both spontaneous and dexamethasone induced parturitions are preceded by an abrupt fall of the progesterone concentration $24-48 \mathrm{hrs}$. prior to delivery. In cows having normal parturitions there is an increase in the level of prostaglandins in conjunction with a decrease in the progesterone secretion (Fairclough et al. 1975, Edqvist et al. 1976).

The aim of the present investigation was to determine prostaglandin release and its temporal relationship to estrone and progesterone levels after administration of dexamethasone to cows in late stages of pregnancy.

\section{MATERIALS AND METHODS}

Three pregnant cows of the Swedish Red and White Breed (SRB) were used in this study. The animals were six years old and had a previous history of regular gestation periods. The cows were brought to the clinic about 2 weeks prior to the experimental period. From the date of arrival until the end of the experimental period the course of pregnancy was determined by rectal and vaginal examinations.

Cow no. 1 was given $8 \mathrm{ml}$ of a dexamethasone preparation (Opticortenol comp.®) Ciba, Basel, Switzerland, containing 2.5 $\mathrm{mg}$ dexamethasone and $7.5 \mathrm{mg}$ prednisolone per $\mathrm{ml}$ ) intramuscularly twice with an interval of $48 \mathrm{hrs}$. Cows nos. 2 and 3 received $8 \mathrm{ml}$ twice with a $24 \mathrm{hr}$. interval. The length of pregnancy at the time of the first injection was 247, 254 and 254 days, respectively, for cows $1-3$.

* The following trivial names are used:

Dexamethasone: $9 \alpha$-fluoro-16 $\alpha$-methyl-11 $\beta, 17 \alpha, 21$-trihydroxy-1,4pregnadiene-3,20-dione.

Estrone: 3-hydroxy-1,3,5(10)-estratriene-17-one.

Prostaglandin $\mathrm{F}_{2 \alpha}\left(\mathrm{PGF}_{2 \alpha}\right): 9 \alpha, 11 \alpha, 15$-trihydroxyprosta-5,13-dienoic acid.

15-keto-13,14-dihydroprostaglandin $\mathrm{F}_{2 \alpha}: 9 \alpha, 11 \alpha$-dihydroxy-15ketoprost-5-enoic acid.

Progesterone: 4-pregnene-3,20-dione. 
Blood samples were drawn daily until first dexamethasone injection, thereafter blood samples were drawn every third hour until 12-78 hrs. after the end of the induced parturitions (Figs. 1-3). All blood samples were collected into heparinized tubes and centrifuged immediately. The blood plasma was removed and stored below $-15^{\circ} \mathrm{C}$ until analyses were performed.

Blood plasma levels of estrone were determined by radioimmunoassay (Edquist \& Johansson 1972) and progesterone was measured by competitive protein binding (Edqvist et al. 1970). Prostaglandin release was determined through the measurement of the main blood plasma metabolite of prostaglandin $F_{2 \alpha}$, 15-keto-13,14-dihydroprostaglandin $\mathrm{F}_{2 \alpha}$, by a radioimmunoassay technique (Granström \& Kindahl 1976, Kindahl et al. 1976). In this study no attempts have been made to determine blood plasma levels of 15-keto-13,14-dihydroprostaglandin $F_{2 \alpha}$ exceeding $800 \mathrm{pg} / \mathrm{ml}$.

\section{RESULTS}

Relatively weak signs of approaching parturition such as relaxation of the pelvic ligaments, enlargement of the vulva and distension of the udder, were observed two-three days following the second injection of dexamethasone. Cows nos. 1-3 gave birth to living calves 153, 138 and $137 \mathrm{hrs}$., respectively, after the second injection of dexamethasone. Retention of fetal membranes occurred in cows nos. 1 and 2.

The results of the hormonal measurements in cows nos. 1-3 are given in Figs. 1-3.

Prior to the dexamethasone injections the peripheral blood plasma levels of estrone ranged from 0.1 to $0.5 \mathrm{ng} / \mathrm{ml}$. Following the second dexamethasone injection all three cows had a continuous increase of the estrone level reaching maximum concentrations of about 3 to $5 \mathrm{ng} / \mathrm{ml}$ about $30 \mathrm{hrs}$. before the induced parturition. The estrone concentration remained at this level for about $24 \mathrm{hrs}$. and then fell rapidly, and values below $0.5 \mathrm{ng} / \mathrm{ml}$ were seen 24 hrs. later.

The peripheral blood plasma levels of the prostaglandin metabolite were below $0.2 \mathrm{ng} / \mathrm{ml}$ in all cows prior to the first dexamethasone injection. After the second injection of dexamethasone a gradual increase of the 15-keto-13,14-dihydroprostaglandin $\mathrm{F}_{2 \alpha}$ levels occurred followed by an abrupt rise 6-18 hrs. before parturition and then reaching maximum concentrations $>800$ 


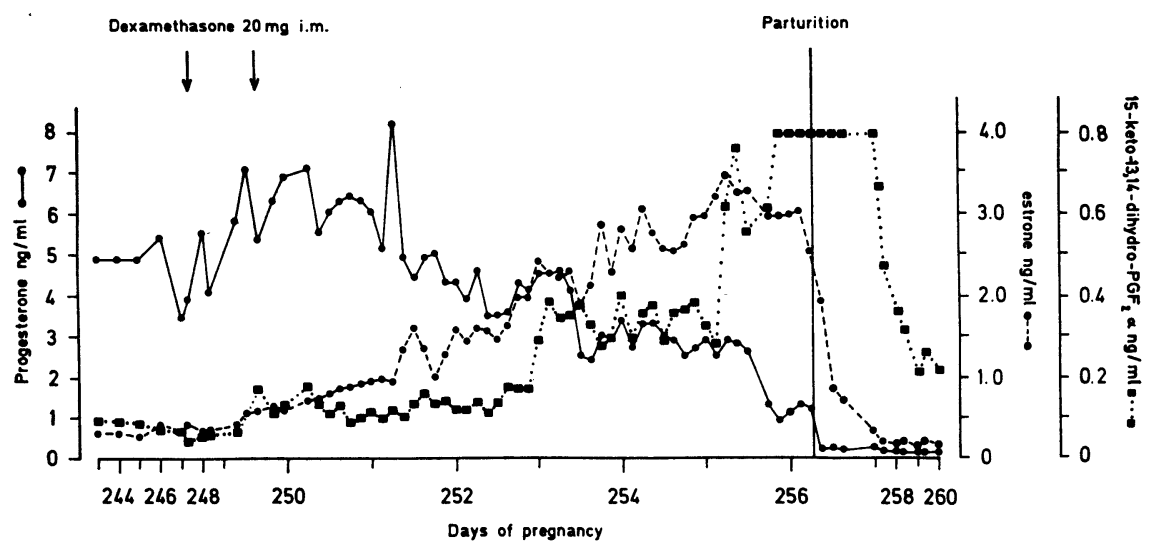

Fig u r e 1. Peripheral blood plasma levels of estrone ( $\bullet \ldots \ldots \ldots \ldots . . . \cdots)$ ), progesterone (๑) and 15-keto-13,14-dihydro-

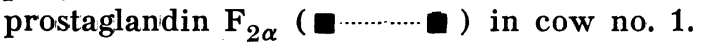

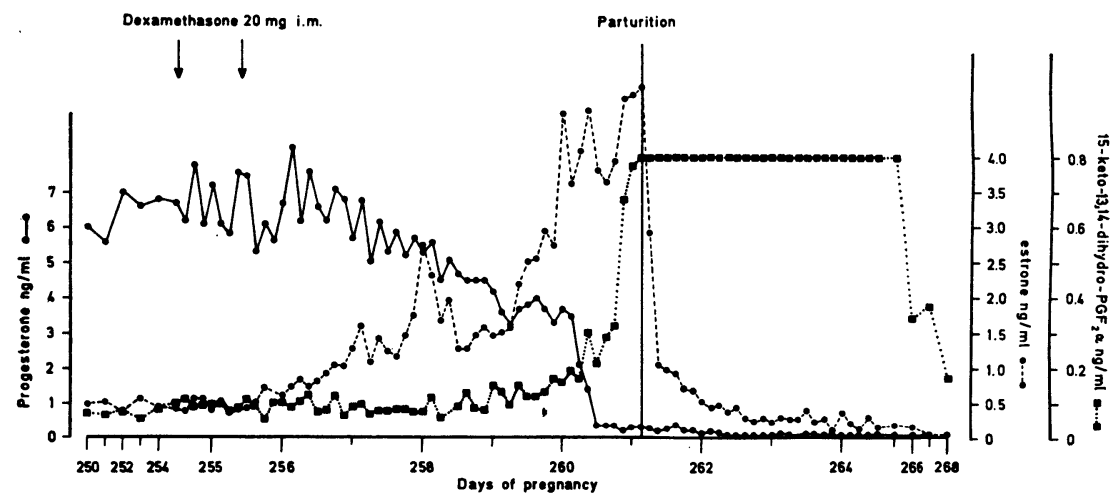

Fi g u r e 2. Peripheral blood plasma levels of estrone ( $\bullet . \cdots \cdots \cdots \cdots \cdots \cdot \cdots)$ ), progesterone ( $\bullet)$ and 15-keto-13,14-dihydroprostaglandin $F_{2 \alpha}(a \cdots \cdots)$ ) in cow no. 2.

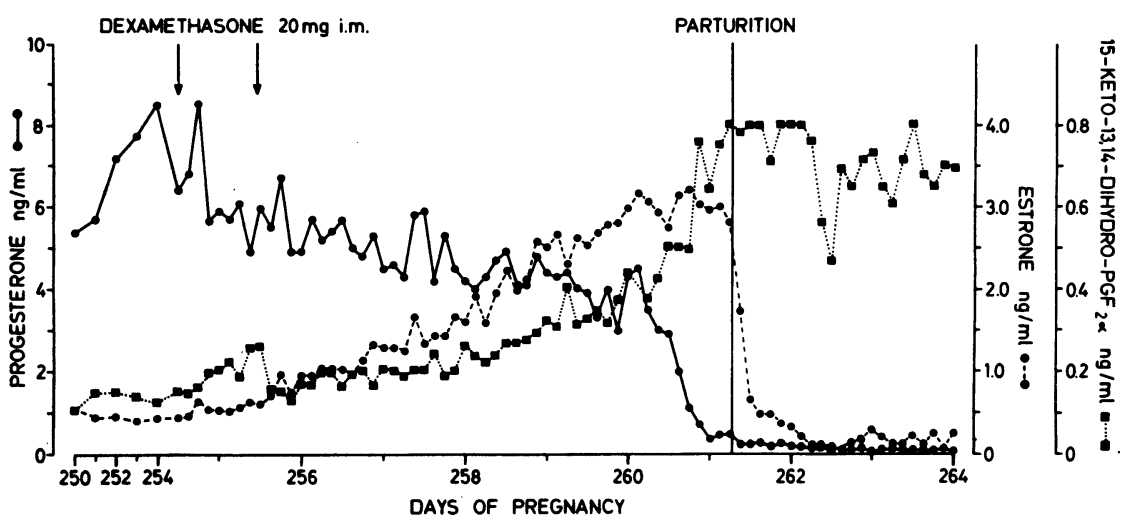

F i g u r e 3. Peripheral blood plasma levels of estrone ( $\bullet \cdots \cdots \cdots \cdots \cdots \cdot(\bullet)$, progesterone $(\bullet-\bullet)$ and 15-keto-13,14-dihydroprostaglandin $\mathrm{F}_{2 \alpha}(\boldsymbol{\square} \ldots \ldots \ldots \ldots)$ in cow no. 3 . 
$\mathrm{pg} / \mathrm{ml}$ immediately prior to parturition. These high concentrations were maintained for up to four days after delivery.

Peripheral plasma concentrations of progesterone decreased gradually from the day of the first dexamethasone injection until about 24 hrs. before delivery, when a marked drop of the concentration occurred. After parturition the progesterone levels were below $0.5 \mathrm{ng} / \mathrm{ml}$ in all cases.

\section{DISCUSSION}

The pre-experimental hormone levels found in the present study agree favourably with previous studies in the same breed of cows (Edqvist et al. 1972, 1973). The gradual decrease of progesterone concentrations similar to that found here, during the time period between injections of dexamethasone and about 24 hrs. before the occurrence of parturition, is also found during the course of the last month of pregnancy in cows delivering at expected time (e.g. Pope et al. 1969, Donaldson et al. 1970, Stabenfeldt et al. 1970, Robertson 1972, Fairclough et al. 1975). Assuming a constant production rate of progesterone this gradual decrease is likely to reflect an increased clearance. Comline et al. (1974) found higher progesterone levels in peripheral blood plasma when compared to blood plasma draining the uterus in cows in late stages of pregnancy, indicating that the fetalplacental unit was able to clear progesterone. The same jugular vein/utero-ovarian vein blood plasma difference has been reported by Fairclough et al. and Evans \& Wagner (1976). In sheep Anderson et al. (1975) demonstrated increased placental steroid 17-hydroxylase in response to glucocorticoids. Thus opening the possibility for progesterone to be converted to estrone (Flint et al. 1975, Steele et al. 1976).

The gradual decrease of the progesterone concentration seen after the injection of dexamethasone in this study may reflect the utilization of progesterone for estrogen production. The increased peripheral plasma levels of estrone following dexamethasone treatment will thus be a logical result of this constructive catabolism.

Exogenous injections of prostaglandin $F_{2 \alpha}$ have been shown to act luteolytically in the pregnant cow (Lauderdale 1972, Lamond et al. 1973, Edquist \& Lindell 1974). Increased levels of the prostaglandin metabolite were observed in this study to occur during the course of the gradual progesterone decline and 
estrogen rise. This was followed by an abrupt and marked increase in the prostaglandin metabolite level coinciding with the final drop of the progesterone levels during the last $24 \mathrm{hrs}$. prior to parturition. Whether the continuous increase of the prostaglandin metabolite seen after the dexamethasone injections here can result in some type of "slow" luteolysis is not known. Although in general the inhibitory action of prostaglandin on the bovine corpus luteum is regarded as an "all or none phenomenon", the above-mentioned assumption can not be ruled out.

In the normal calving cow Fairclough et al. reported increased utero-ovarian prostaglandin $\mathrm{F}_{2 \alpha}$ concentrations $48-24 \mathrm{hrs}$. before term, and Edqvist et al. (1976) found increased peripheral blood plasma levels of 15-keto-13,14-dihydroprostaglandin $\mathrm{F}_{2 \alpha}$ before the pre partum progesterone drop.

The physiological mechanism responsible for the release of prostaglandin at the relatively precise time prior to parturition in the cow is not known. Most works lend support to the idea that estrogen might be involved in triggering prostaglandin release. In this study the gradual increase of the prostaglandin metabolite following the dexamethasone treatment occurred after the increase of the peripheral blood plasma level of estrone. Furthermore, the maximum levels of estrone preceded those of the prostaglandin metabolite. All cows had considerably high levels of the prostaglandin metabolite for several days post partum. When designing the present study, such a release pattern was not foreseen and thus an adequate sampling regime for the accurate description of this post partum pattern is lacking in the present investigation. However, it can be concluded that a substantial amount of prostaglandins are released during the immediate post partum period after dexamethasone injections to cows in late stages of pregnancy. The same post partum release pattern has also been observed in normal delivering cows. Whether these high levels are of importance for the release of hormones from the pituitary, e.g. prolactin (Louis et al. 1974) or whether they reflect tissue changes associated with uterine involution remains to be determined.

The time interval between injections of corticosteroids and occurrence of parturition found here agrees with previous experiments carried out in cows at this stage of gestation (Adams \& Wagner 1970, Edqvist et al. 1972, Bailey et al. 1973 among others). A shorter time interval between administration of the 
drug and parturition is found when the dexamethasone has been administered at a later stage of gestation (Wagner et al. 1974, Evans \& Wagner 1976).

Signs of approaching delivery were in general less pronounced and had a shorter duration as compared to cows calving normally at expected time. This is likely due to the relatively short period of preparation for calving e. g. the estrone increase lasting seven-eight days for the cows in the present study as compared to 20-30 days in normally calving cows (Edquist et al. 1973, Smith et al. 1973, Robertson 1974). The retention of fetal membranes found in two of the cows in the present study is in agreement with previous reports on dexamethasone induced parturitions (e.g. Adams \& Wagner 1970, Edqvist et al. 1972).

\section{REFERENCES}

Adams, W. M. \& W. C. Wagner: The role of corticoids in parturition. Biol. Reprod. 1970, 3, 223-228.

Anderson, A. B., A. P. F. Flint \& A. C. Turnbull: Mechanism of action of gluccocorticoids in induction of ovine parturition: Effect of placental steroid metabolism. J. Endocr. 1975, 66, 61-70.

Bailey, L. F., M. W. McLennan, D. M. McLean, P. R. Hartford \& G. L. Munroe: The use of dexamethasone trimethyl acetate to advance parturition in dairy cows. Austr. vet. J. 1973, 49, 567-573.

Comline, R. S., L. W. Hall, R. B. Lavelle, P. W. Nathanielz \& M. Silver: Parturition in the cow: Endocrine changes in animals with chronically implanted catheters in the foetal and maternal circulations. J. Endocr. 1974, 63, 451—472.

Donaldson, L. E., J. M. Bassett \& G. D. Thorburn: Peripheral plasma progesterone concentration of cows during puberty, oestrus cycle, pregnancy and lactation, and the effects of undernutrition or exogenous oxytocin on progesterone concentration. J. Endocr. 1970, 48, 599-614.

Edqvist, L.-E. \& E. D. B. Johansson: Radioimmunoassay of oestrone and oestradiol in human and bovine peripheral plasma. Acta endocr. (Kbh.) 1972, 71, 716-730.

Edqvist, L.-E. \& J.-O. Lindell: The effect of prostaglandin on gonadal hormones and the course of pregnancy in the cow. Proc. 12th Nord. vet. Congr. 1974, 275.

Edqvist, L.-E., L. Ekman, B. Gustafsson \& G. Åström: Progesterone levels in the bovine peripheral plasma measured by the competitive protein binding technique. Zbl. Vet.-Med. 1970, A 17, $899-908$.

Edqvist, L.-E., L. Ekman, B. Gustafsson, S.-O. Jacobsson, E. D. B. Johansson \& J.-O. Lindell: Peripheral plasma levels of oestrone and progesterone in pregnant cows treated with dexamethasone. Acta endocr. (Kbh.) 1972, 71, 731-742. 
Edqvist, L.-E., L. Ekman, B. Gustafsson \& E. D. B. Johansson: Peripheral plasma levels of oestrogens and progesterone during late bovine pregnancy. Acta endocr. (Kbh.) 1973, 72, 81-88.

Edqvist, L.-E., H. Kindahl \& G. H. Stabenfeldt: On the role of prostaglandins in bovine parturition. Proc. 8th Int. Congr. Anim. Reprod. Comm. Abstracts, Krakow 1976, 76.

Evans, L. \& W. C. Wagner: Bovine plasma oestrogens, progesterone and glucocorticoids during dexamethasone induced parturition. Acta endocr. (Kbh.) 1976, 81, 385-397.

Fairclough, R. J., J. T. Hunter \& R. A. S. Welch: Peripheral plasma progesterone and utero-ovarian prostaglandin $\mathrm{F}$ concentrations in the cow around parturition. Prostaglandins 1975, 9, 901-914.

Flint, A. P. F., A. B. Anderson, P. A. Steele \& A. C. Turnbull: The mechanism by which foetal cortisol controls the onset of parturition in the sheep. Biochem. Soc. Trans. 1975, 3, 1189-1194.

Granström, E. \& H. Kindahl: Radioimmunoassay for prostaglandin metabolites. In Advances in Prostaglandin and Thromboxane Research. B. Samuelsson \& R. Paoletti, eds., Raven Press, New York 1976, Vol. 1, 81-92.

Hoffman, B., D. Schams, T. Gimenez, M. L. Ender, C. Herrman \& H. Karg: Changes of progesterone, total oestrogens, corticoids, prolactin and LH in bovine peripheral plasma around parturition with special reference to the effects of exogenous corticoids and a prolactin inhibitor, respectively. Acta endocr. (Kbh.) 1973, 73, 385-395.

Kindahl, H., L.-E. Edqvist, A. Bane \& E. Granström: Blood levels of progesterone and 15-keto-13,14-dihydro-prostaglandin $\mathrm{F}_{2 \alpha}$ during the normal oestrous cycle and early pregnancy in heifers. Acta endocr. (Kbh.) 1976, 82, 134-149.

Lamond, D. R., R. V. Tomlinson, M. Drost, D. M. Henricks \& W. Jöchle: Studies of prostaglandin $F_{2 \alpha}$ in the cow. Prostaglandins 1973, 4, $269-284$.

Lauderdale, J. W.: Effects of $\mathrm{PGF}_{2 \alpha}$ on pregnancy and estrous cycle of cattle. J. Anim. Sci. 1972, 35, 246.

Louis, T. M., J. N. Stellflug, H. A. Tucker \& H. D. Hafs: Plasma prolactin, growth hormone, luteinizing hormone and glucocorticoids after prostaglandin $\mathrm{F}_{2 \alpha}$ in heifers (38295). Proc. Soc. exp. Biol. (N.Y.) 1974, 147, 128-133.

Pope, G. S., S. K. Gupta \& I. B. Munro: Progesterone levels in the systemic plasma of pregnant, cycling and ovariectomized cows. J. Reprod. Fertil. 1969, 20, 369-381.

Robertson, H. A.: Sequential changes in plasma progesterone in the cow during the oestrous cycle, pregnancy, at parturition and post-partum. Canad. J. Anim. Sci. 1972, 52, 645-658.

Robertson, H. A.: Changes in the concentration of unconjugated oestrone, oestradiol-17 $\alpha$ and oestradiol-17 $\beta$ in the maternal plasma of the pregnant cow in relation to the initiation of parturition and lactation. J. Reprod. Fertil. 1974, 36, 1-7. 
Smith, V. G., L. A. Edgerton, H. D. Hafs \& E. M. Convey: Bovine serum oestrogens, progestins and glucocorticoids during late gestation. J. Anim. Sci. 1973, 36, 391-395.

Stabenfeldt, G. H., B. I. Osburn \& L. L. Ewing: Peripheral plasma progesterone levels in the cow during pregnancy and parturition. Amer. J. Physiol. 1970, 218, 571-575.

Steele, P. A., A. P. Flint \& A. C. Turnbull: Activity of steroid C-17,20lyase in the ovine placenta: Effect of exposure to fetal glucocorticoid. J. Endocr. 1976, 69, 239-246.

Wagner, W. C., R. L. Willham \& L. E. Evans: Controlled parturition in cattle. J. Anim. Sci. 1974, 38, 485—489.

\section{SAMMANFATTNING \\ Prostaglandinfrisläppning vid dexamethason-inducerad förlossning hos ko.}

Tre dräktiga kor av SRB-ras ingick i försöket. Ko nr. 1, dräktig 247 dagar, gavs $20 \mathrm{mg}$ dexamethason i.m. med 48 timmars intervall. Ko nr. 2 och 3 gavs samma dos i.m. men med 24 timmars intervall. Behandlingen resulterade $i$ prematur förlossning 153, 138 och 137 timmar efter sista injektionen. Under försöksperioden uttogs blodprover var 3:e timma. Blodproverna analyserades med avseende på östron, progesteron samt huvudmetaboliten till prostaglandin $\mathrm{F}_{2 \alpha}$ hos ko, 15-keto-13,14-dihydroprostaglandin $\mathrm{F}_{2 \alpha}$. Den perifera blodplasmakoncentrationen av östron ökade efter dexametasonbehandlingen från cirka $0.5 \mathrm{ng} / \mathrm{ml}$ till maximalt $3-5 \mathrm{ng} / \mathrm{ml}$ som uppmättes under 24-timmansperioden närmast före förlossningen. Efter partus sjönk perifera blodplasmanivån av östron snabbt till värden under $0.5 \mathrm{ng} / \mathrm{ml}$. Perifera blodplasmanivån av progesteron sjönk långsamt och gradvis från cirka $5-8 \mathrm{ng} / \mathrm{ml}$ till cirka $3 \mathrm{ng} / \mathrm{ml}$ vilket uppmättes ungefär 24 timmar före förlossningen. Därefter sjönk progesteronnivån kraftigt och värden nära noll registrerades strax före och i samband med förlossningen. Koncentrationen av 15-keto-13,14-dihydroprostaglandin $\mathrm{F}_{2 \alpha}$ ökade långsamt fram till ungefär 24 timmar före förlossningen då en snabb ökning av koncentrationen noterades samtidigt med den kraftiga progesteronsänkningen. Sammanfattningsvis kan konkluderas att östronuppgången föregick ökningen av prostaglandinmetaboliten och att den slutliga progesteronsänkningen inträffade samtidigt med att koncentrationen av prostaglandinmetaboliten ökade kraftigt. Den höga nivån av prostaglandinmetaboliten kvarstod i upp til fyra dygn efter förlossningen.

(Received March 15, 1977).

Reprints may be requested from: Dr. J.-O. Lindell, the Department of Obstetrics and Gynaecology, Royal Veterinary College, S-750 07 Uppsala, Sweden. 